\title{
7. Fiskális és monetáris eszközök a járványügyi veszélyhelyzet gazdasági hatásainak mérséklésére
}

\author{
NAGY ZOLTÁN
}

\section{Bevezető gondolatok}

A vírusjárvány miatt bevezetett kormányzati intézkedések, illetve a járványtól való félelem komoly gazdasági kihívások elé állították a világgazdaságot, így a magyar gazdaságot is. A következmények csak kalkulálhatók, mivel a könyv és a fejezet elkészítése alatt még folyamatban van a különleges jogrend, a járványügyi intézkedések. A gazdasági válságok nem jelentenek újdonságot a kutatók számára, de a jelenlegi válság, annak kialakulása és ezzel összefüggő hatása újszerú a gazdaságtörténetben, talán a háborús helyzethez hasonlítható leginkább. ${ }^{1}$ A legnagyobb kihívást a helyzet kezelése jelenti, hiszen a járványügyi veszélyhelyzet komoly gazdasági és társadalmi károkat okoz. Tulajdonképpen nem lehet tökéletes döntést hozni, csak kevésbé rosszat. A különleges jogrendi korlátozó intézkedések csökkentik a vírus terjedését, az egészségügyi ellátórendszer terheltségét, de emellett komoly gazdasági károkat okoznak, és ennek is vannak társadalmi, egészségügyi hatásai. A gazdasági válság önmagában nem kezelhető különleges jogrendként, de a különleges jogrendi válságkeze-

1 Hasonló álláspontra lásd: Kádár, 2021.

Prof. Dr. Nagy Zoltán, PhD

zoltan.nagy@mfi.gov.hu

főosztályvezető (Mádl Ferenc Összehasonlító Jogi Intézet)

egyetemi tanár (Miskolci Egyetem Állam- és Jogtudományi Kar, Államtudományi Intézet, Pénzügyi Jogi Tanszék)

Nagy, Z. (2021) 'Fiskális és monetáris eszközök a járványügyi veszélyhelyzet gazdasági hatásainak mérséklésére' in Nagy, Z., Horváth, A. (szerk.) A különleges jogrend és nemzeti szabályozási modelljei, 174-191. o. Budapest: Mádl Ferenc Összehasonlító Jogi Intézet.

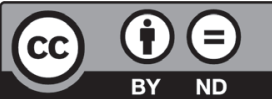


lésnek van gazdasági válságkezelési kimenete. ${ }^{2}$ Mindenesetre a kormányok politikájában kifejezésre jutott a gazdasági érvek mellett az emberi élet védelme, azaz a járvány esetén elsődleges a vírus elleni védekezés, és csak ezt követi a gazdasági hatások mérséklése, amit a fejlett országokban lehetôvé tesz a kiépített szociális háló. Azonban a fejlődő országokban a gazdasági válság emberéleteket követelhet. A szakirodalmi becslések alapján a válság miatt duplájára növekedhet az akut éhezéstől szenvedők száma. ${ }^{3}$

Miben tér el ez a válság a korábbi válságoktól? A gazdaság soha sincs nyugvó állapotban, hanem mindig változik, gazdasági növekedés vagy visszaesés ciklusában van. A konjunktúraciklus-elméletek szerint azonban a kiváltó okok eltérőek lehetnek, exogén és endogén magyarázatok jelentőségére egyaránt rámutat a közgazdaságtan. A jelenlegi válságot egyértelmủen külső, gazdaságon kívüli tényező váltotta ki, a koronavírus-járvány. ${ }^{4}$ Ez egyedi az eddigi modern gazdaságtörténetben, viszont magán hordozza a gazdasági válságok jó néhány közös jellemzőjét. A beruházások visszaesnek, a fogyasztási kiadásokat visszafogják, nő a munkanélküliség, csökken a kibocsátás, esik a GDP. ${ }^{5}$ Mindezek a hatások azonban eltérően érinthetik az egyes országokat attól függően, hogy milyen gazdasági, társadalmi állapotban vannak, mennyire sérülékeny a gazdaságuk, amire jó példaként hozható az előző, 2008-as gazdasági válság. ${ }^{6}$ Azonban a jelenlegi gazdasági válságnál a szakirodalom arra mutatott rá, hogy rövid távon ezek nem magyarázzák a krízis hatásait, és a válság kimenetelére sem adnak megoldást. ${ }^{7}$ Jól látható tehát, hogy ez a krízis más jellemzőkkel bír, így új kihívások eléállította a gazdaságpolitikát. A járvány miatt bevezetett kormányzati korlátozó intézkedések indították el a kereslet visszafogását, és egyben kínálati korlátozást is okoztak a gazdaságban. A keresleti és kínálati sokk együtt jelentkezett. A fogyasztás és a kibocsátás elé állított adminisztratív korlátok és a járvány miatt jelentkező óvatosság egyaránt éreztette hatását, ${ }^{8}$ azonban eltérő mértékben jelentkezett a gazdaság egyes területein. ${ }^{9}$ Azokban az országokban, ahol például a turizmus, az idegenforgalom a nemzetgazdaság jelentős

2 Vö.: Alaptörvény 36. cikk (6) bekezdés.

3 Botos, 2020, 385-388. o. A szerző rámutat arra, hogy a fejlődő országokban előfordulhat az a helyzet, hogy a válság okozta munkanélküliség miatt éhen is halhatnak az emberek. Erre vannak gazdaságtörténeti példák is, mint az 1930-as években a gazdasági válság idején. A jelenlegi válság kapcsán a becslések szerint $420-$ 580 millió ember kerülhet mélyszegénységbe.

4 Samuelson-Nordhaus, 2012, 389-391. o. A szerzők rámutatnak, hogy ilyen külső tényező lehet a háború, a forradalom, a népességmozgás és akár a tudományos innovációk is.

5 Samuelson-Nordhaus, 2012, 388-389. o.

6 Nagy, 2019, 5-6. o.

7 Czeczeli et al., 2020, 323. o.

8 Koppány, 2020, 449. 0.

9 Terták-Kovács, 2020, 369-370. o. A koronavírus-járvány okozta veszélyhelyzeti intézkedések eltérő mértékben sújtották az egyes ágazatokat. A szerzők rámutatnak arra, hogy a legnagyobb veszteséget a szállás, vendéglátás, szállítás és kiskereskedelem szenvedte el az ipar és a szabadidős, művészeti és egyéb szolgáltatások mellett. 
részét teszi ki, a válság erôteljesebb. ${ }^{10} \mathrm{~A}$ gazdaságpolitikának tehát a válságból való kilábalás megoldásait ennek megfelelően kell kiválasztania. ${ }^{11}$

A közgazdaság-tudomány különböző irányzatai között jelentős vita van a kormányzati beavatkozásról. ${ }^{12} \mathrm{~A}$ modern vegyes gazdaságban a kormányzati szektor szerepe jelentős, de ennek mértékéról, a piaci kudarcok orvoslásáról napjainkban is folyik a vita. A piaci kudarcok mellett a kormányzati beavatkozás kudarcát is ismeri a szakirodalom. ${ }^{13} \mathrm{~A} 2008$-as gazdasági válság megoldásában erőteljes szerepet játszottak a fiskális és monetáris politika eszközei, ami alapján a jelenlegi kormányok is megpróbálják ezt a válságkezelési módszert alkalmazni, nem várva meg a piac önszabályozó mechanizmusainak az érvényesülését. ${ }^{14}$

A 2008-as gazdasági válság jelentős kihívás volt a Gazdasági és Monetáris Unió akkor múködő mechanizmusaival szemben. Az uniós válságkezelésben egyrészt kiemelkedő szerepet töltöttek be az Európai Központi Bank likviditásnövelő, mennyiségi lazítást eredményező intézkedései, különösen az eszközvásárlási programok. Másrészt lényeges rövid távú, illetve tartós, rendszerszintú intézkedések történtek az európai gazdasági kormányzás rendszerében. Jellemzően kormányközi szerződések révén a makrogazdasági stabilitást előmozdító preventív és kiigazító mechanizmusok kerültek kiépítésre. ${ }^{15}$

Ugyanakkor az uniós költségvetés közvetlen válságkezelésre (stabilizációs funkció teljesítésére) alapvetó strukturális és funkcionális tényezők miatt volt képes. ${ }^{16} \mathrm{~A}$ közös költségvetés definitív módon kiegyensúlyozott, annyit költ az unió, amennyi bevétele van a tagállami és közös forrásokból. ${ }^{17}$ Ezért a fiskális politika területén a tagállamoknak elsősorban maguknak kellett szembenézniük a recesszióval. Az egyes tagállamok rendkívül eltérő államháztartási pozíciói eltérő fiskális impulzusokra adtak lehetőséget. Mindezek nagymértékben növelték az egyes tagállamok közötti diverzitásokat.

A jelenlegi helyzetben az Európai Unió tagállamai érzékelték a válság súlyosságát. Még nincsenek végleges számok, csak várható előrejelzések, de ezek súlyos gazdasági visszaesést

10 A gazdaság több területére a korlátozó szabályok sokkszerúen hatottak. A légitársaságok, az idegenforgalomhoz kapcsolódó vendéglátás és szállodaipar, a színházak, mozik, koncertek, rendezvények szervezése a teljes korlátozó szabályokkal szembesült. Ugyanakkor a gazdaság ilyen területeihez kapcsolódó szektoroknak egyaránt csökkenő kereslettel kellett számolniuk.

11 Muraközy, 2012, 21-44. o.

12 Muraközy, 2010, 794-795. o.

13 Stiglitz, 2000, 25-35. o.

14 Bessenyei, 2020, 181-185. o.

15 Szegedi, 2019, 101. o. Az Európai Unió a válságot követő évtizedben teljesen átalakította a pénzpiacok európai felügyeleti rendszerét, majd hozzákezdett az Európai Bankunió kialakításához, a szanálási mechanizmusok és a betétbiztosítási rendszer teljes reformjához. A válság közgazdasági kérdéseiről lásd bővebben: Halmai, 2014; Halmai, 2020a, 277-282. o.; Halmai, 2020b, 259-275. o.

16 Halmai, 2020a, 20-53. o.

17 Halász, 2018, 50-54. o., 149. o. A szerző kiemeli, hogy az uniós költségvetésben a bevételeknek és a kiadásoknak egyensúlyban kellett lenniük, így nem tervezhető hiány és többlet sem. Ha mégis felmerül hiány, annak kölcsönnel történő fedezésére költségvetési módosítást kell készíteni. A szabályozás szerint elkerülhetetlen, kivételes vagy előre nem látható körülmények felmerülése esetén terjeszthet elő az Európai Bizottság költségvetés-módosítást. 
jeleznek annak függvényében, hogy ezek az előrejelzések a júniusi járványhelyzet alapján készültek, és még nem számoltak a járványhelyzet második hullámával. ${ }^{18} \mathrm{~A}$ jelenlegi helyzetben azonban még a járvány terjedő narratíváival is számolni kell, amelyek hatással vannak a pandémia kezelése mellett a gazdasági eszközök hatékony érvényesülésére. ${ }^{19} \mathrm{~A}$ járványra az első azonnali reakció 2020-ban az elkerülhetetlen korlátozó intézkedések meghozatala volt. A rendkívüli jogrend bevezetése a bezárkózást hozta el a tagállamok számára, de globálisan is gyengítette a nemzetközi együttmúködést.

Költségvetési szempontból sajátos helyzet alakult ki, mivel az uniós költségvetési időszak végét jelenti 2020, így az uniós költségvetésből csak kisebb mértékű források állnak rendelkezésre. ${ }^{20} \mathrm{Az}$ első sokk után azonban már az EU is reagált a járvány gazdasági hatásainak mérséklésére. ${ }^{21} \mathrm{~A}$ legnagyobb lépést azonban az unió közös kötelezettségvállalása jelentette, amelynek keretében az EU vesz fel hitelt, és így biztosít forrást a tagállamok számára, amire eddig nem volt példa. ${ }^{22} \mathrm{Ez}$ a gazdasági integráció irányába tett lépésként is értékelhető, hiszen a tagállamok gazdasági szolidaritást vállalnak egymásért úgy, hogy közösen vesznek fel hitelt és vállalják annak visszafizetését. ${ }^{23}$

\section{A magyar fiskális politika a járványügyi veszélyhelyzetben}

A fiskális politika folyamataira hatással van a gazdasági válság, illetve a költségvetési politika is hatással van a válságra, így az állam gazdasági szabályozó szerepe felértékelődik. A gazdaságpolitika fontos célkitúzése az alacsony mértékú munkanélküliség, a gazdasági növekedés, a stabil, alacsony infláció. ${ }^{24}$ Ezeket a célokat szem elôtt tartva kezelik a kormányok a válság következményeit, illetve még folyamatában csökkentik a válság gazdaságra mért káros hatásait. A fiskális politika eszközrendszere a költségvetés szabályrendszeréhez

18 Jackson et al., 2020, 5-13. o. A kutatás az euróövezetben az OECD előrejelzése alapján 2020-ra 9,1\%-os, az IMF alapján 7,5\%-os, a Világbank alapján szintén 9,1\%-os gazdasági visszaesést vár a GDP-hez viszonyítva. Az Európai Bizottság az euróövezetre 7,7\%-os, a teljes EU-ra 7,4\%-os gazdasági visszaesést prognosztizál.

19 Shiller, 2020, 9-21. o. A narratív közgazdaságtan részletesen elemzi, hogy a közhiedelmek milyen szerepet játszanak a gazdasági eseményekben. A gazdasági válságok és maga a járvány is létrehoz történeteket, amelyek vírusként terjednek és befolyásolják a gazdasági döntéseket.

20 Szíjártó, 2020, 1-13. 0.

21 Balázs, 2020, 5-8. o. A szerző rámutat, hogy a válság gazdasági hatásainak mérséklésére feloldották a költségvetési hiányra és az állami támogatásokra vonatkozó korlátozó szabályokat, továbbá 37 milliárd eurót átcsoportosítottak a strukturális alapból a vírus elleni védekezésre. Az Európai Beruházási Bank 200 milliárd euró keretösszegben kínál beruházási hiteleket, az Európai Bizottság 100 milliárd eurós munkabért támogató alapot hozott létre a tavaszi időszakban.

22 Csürös, 2015, 122-155. o.

23 Botos, 2020, 392-395. o. Az Európai Unió 750 milliárd eurós keretet fogadott el, amelynek egy része támogatás formájában kerül folyósításra (390 milliárd euró), míg a másik része hitellehetőséget biztosít a tagállamok számára (360 milliárd euró).

24 Samuelson-Nordhaus, 2012, 570. o. 
kapcsolódva hat a gazdaságra. Az eszközöket többféle aspektusból lehet megközelíteni, beszélhetünk közvetett és közvetlen eszközökrőll25 vagy a költségvetés bevételeire és kiadásaira ható eszközökról egyaránt.

A gazdasági válság következtében a költségvetési politika kettős kihívás elé került mind a bevételi, mind a kiadási oldal tekintetében, így az ennek orvoslásához kapcsolódó eszközöket a két szegmens vizsgálatával kell bemutatni. A válság következtében a bevételi oldalon számolni kell többek között a csökkenő adóbevételekkel, a munkanélküliség növekedésével, a fogyasztás visszaesésével az elmaradó beruházások miatt. A kiadási oldalon a támogatások növelése miatt a kiadások növekedésével kell számolni. Ugyanakkor az átcsoportosítások, szerkezeti változások átstrukturálják a költségvetést, ami a költségvetési törvény módosításában ölt testet. A magyar fiskális politika 2008-tól kezdődően célként túzi ki a takarékos állami gazdálkodást és a felelős költségvetési politikát. A költségvetési politika alapvető célja lett az államadósság hosszú távon fenntartható szintjének az elérése, amit a költségvetési politika az egyensúlyközeli állapotának hosszú távú biztosítása révén kíván biztosítani, azaz a fiskális politika legfőbb meghatározója az államadósság stabilizálása volt. ${ }^{26} \mathrm{Az}$ államadóssággal pedig összefügg a költségvetési hiány, mivel főszabályként az államadósság a hiány finanszírozása révén keletkezik. ${ }^{27} \mathrm{~A}$ költségvetési fegyelem erősítése szükségszerü lépés volt, mert az államadósság szintje folyamatosan nőtt a jelentős mértékú államháztartási hiány miatt. ${ }^{28}$

A költségvetési hiány mértékét az uniós jog, a maastrichti szerződés a konvergenciakritériumok meghatározásával szabályozza. A fenntartható államháztartási gazdálkodás egyik fontos feltétele, hogy az államháztartás éves hiánya ne haladja meg a GDP 3\%-át. Ha egy uniós ország nem teljesíti a feltételeket, akkor túlzottdeficit-eljárás indul ellene. Magyarország az Európai Unióba való belépése, azaz 2004 óta túlzottdeficit-eljárás alatt állt 2013-ig, amely évben megszűnt az eljárás. Ennek alapját a két éven keresztül megvalósuló, illetve a további évekre is valószínúsített $3 \%$ alatti költségvetési hiány teremtette meg. ${ }^{29}$

Az államadósság rendszerbeli jelentőségét indokolja az alaptörvényi szabályozás, illetve a költségvetési eljárási rendben az adósságszabály érvényesülése, azaz a gazdálkodás egészét átfogja az a cél, hogy az államadósság folyamatosan csökkenjen, de legalább ne emelkedjen, és hosszabb távon az optimális adósságmérték elérhető legyen (GDP 50\%-a). Tehát a fiskális politika központi jogintézménye lett az államadósság-szabály. ${ }^{30} \mathrm{Az}$ államadósság-szabályra

25 Simon, 2019, 31-32. o. A szerző a közvetlen eszközök alatt a költségvetéshez kapcsolódó konkrét döntést jelent, míg a közvetett eszközök külön egyedi beavatkozás nélkül fejtik ki a hatásukat, mint például az adók.

26 A takarékos állami gazdálkodásról és a költségvetési felelősségről szóló 2008. évi LXXV. törvény. A törvény bevezető rendelkezései elvárásként fogalmazzák meg a fegyelmezett, átlátható és hosszú távon fenntartható költségvetési politika megteremtését és folytatását a hosszú távú gazdasági versenyképesség biztosítása mellett.

27 Vígvári, 2005, 175-178. o.

28 Sivák-Szemlér-Vígvári, 2013, 49-51. o. 2006-ban az államháztartási hiány mértéke a GDP 9,4\%-a volt.

29 Sivák-Szemlér-Vígvári, 2013, 61. o.

30 Kovács, 2016, 320-326. o. 
vonatkozó rendelkezéseket az Alaptörvény mellett a stabilitási törvény fejti ki részletesen. ${ }^{31}$ A szabály lényege, hogy a fenntartható államháztartási gazdálkodás és a jövő nemzedékekért vállalt felelősség érdekében az Országgyúlés olyan költségvetési törvényt fogadhat el, amelynek eredményeképpen az államadósság nem haladja meg a teljes hazai össztermék felét, azaz az Alaptörvény által meghatározott optimális államadósság mértékét. Ez általános alapelvnek is tekinthető. ${ }^{32} \mathrm{Az}$ alapelv azért tekinthetó általánosnak - ahogy az indokolás utal rá -, mivel az alapvető jogok érvényesülése, az állam hatékony múködése csak akkor garantálható, ha az ország társadalmi, gazdasági egyensúlyát államháztartási problémák nem veszélyeztetik. ${ }^{33}$ Ezért a költségvetési gazdálkodás, a költségvetési tervezés alapvető általános elve, hogy Magyarország a kiegyensúlyozott, átlátható és fenntartható költségvetési gazdálkodás elvét érvényesíti, amelyet az államháztartás mindkét alrendszerében múködő valamennyi szerv köteles tiszteletben tartani. A kiegyensúlyozottság a kiszámítható állami múködést, az átláthatóság a tájékozott és felelős polgárok részvételével zajló demokratikus közéletet, a fenntarthatóság a jövő nemzedékek sorsáért való felelősségvállalást hivatott szolgálni. ${ }^{34} \mathrm{~A}$ fenntartható államháztartási gazdálkodás többféle pénzügyi elvet ölel fel, de különös jelentősége a korábban említett államadósság-szabálynak van. ${ }^{35}$

Jelenleg azonban az államadósság ezt a mértéket jelentősen meghaladja, ezért az optimális államadósság eléréséig az Országgyûlésnek az államadósság csökkentésére irányuló költségvetést kell elfogadnia. ${ }^{36}$ Nyilvánvalóan az államháztartási gazdálkodásra ható tényezőkben olyan kivételes helyzetek, elháríthatatlan külső okból származó súlyos problémák keletkezhetnek, amelyek orvoslása kapcsán a szigorú szabályoktól eltérést enged az Alaptörvény (nemzetgazdaság tartós visszaesése, nemzetgazdasági egyensúly helyreállítása). A gazdasági válságra utaló szabályt a stabilitási törvény értelmezi kiterjesztő jelleggel, mivel kimondja, hogy a nemzetgazdaság tartós és jelentős visszaeséseként kell értelmezni minden olyan esetet, amikor az éves bruttó hazai termék reálértéke csökken. Ebben az esetben a stabilitási törvény megengedi, hogy a kormányzati szektor hiánya meghaladja a bruttó hazai termék 3\%-át, illetve azt, hogy az államadósság mutatója csökkenjen. ${ }^{37}$ A járvány következtében kialakult gazdasági válság tehát indokolja az államadósság-szabálytól való eltérést. Az államadósság növekedése a gazdasági válság esetén természetes folyamat, hiszen az állam túlköltekezése, a támogatások növelik a költségvetési hiányt. A hiány nagyságánál fontosabb a pluszforrások hasznosulása, hiszen ha a költségvetési pénzek elköltése haté-

31 Alaptörvény 36. cikk (4)-(5) bekezdés; Magyarország gazdasági stabilitásáról szóló 2011. évi CXCIV. törvény (a továbbiakban: Gst.) 2-10/F. \$.

32 Alaptörvény $\mathrm{N}$ ) cikk.

33 Nagy, 2014b, 5. o.

34 Drinóczi, 2012, 2-6. o.

35 Barcza, 2015, 444-447. o. A szerző rámutat arra, hogy a közgazdasági elméletek eltérően ítélik meg az optimális államadósság mértékét.

36 Nagy, 2014a, 12. o.

37 Gst. 7. \$. 
konyan történik, akkor az nemcsak a válságból való kilábalást alapozza meg, hanem a jövőbeni gazdasági növekedést is. ${ }^{38}$

A GDP jelentôs csökkenése és a nemzetgazdasági egyensúly helyreállítása egyaránt növelik az államadósságot, mivel az államadósság-mutató a GDP-hez van kötve, önmagában a GDP esése növeli az államadósság mértékét anélkül, hogy a költségvetési hiány változna. A költségvetést a válság érintheti a bevételi oldalról a bevételek elmaradása miatt, és érintheti kiadási oldalról a központi költségvetési támogatások növelése kapcsán.

A központi költségvetés kedvezőtlen alakulására az államháztartási törvény a rendkívüli intézkedések körében ad megoldást, amelynek célja az év közben meghozott kormányzati feladatok megvalósítása és a kiegyensúlyozott költségvetési gazdálkodás fenntartása. A korábbi szabályozást egészíti ki a jogalkotó az átmeneti intézkedésekkel, amelyek a veszélyhelyzettel vannak összefüggésben. A jogalkotó széles körú jogosítványokkal ruházza fel a Kormányt: a költségvetési törvényben nem szereplő költségvetési kiadásokat teljesíthet, illetve rendkívüli fizetési kötelezettséget írhat elő. A különleges jogrendre vonatkozó rendelkezés enyhíti a közterhek szabályozását, azaz el lehet térni a fizetési kötelezettségeket megállapító szigorú eljárási és anyagi jellegú szabályoktól, amelynek mértékét a gazdasági visszaesés és az egyensúly helyreállításához szükséges mértékben határozza meg a törvény. ${ }^{39}$ A szükséges mérték megitélése vitára adhat okot, mivel eddig még ismeretlen, az egész országot érintő veszélyhelyzetről van szó. A szakirodalmi álláspont is rámutat arra, hogy más szükségességi és arányossági mércét kell használni az eltérő gazdasági és élethelyzet miatt. A szükséges mérték megítélése nagyon nehéz, hiszen csak a válságot követően lehet megítélni, hogy a szabályoktól való eltérés szükséges volt-e. Kérdés tehát, hogy veszélyhelyzetben mit kell ez alatt érteni. ${ }^{40} \mathrm{~A}$ jogalkotó az Alaptörvény szabályozásában tekintettel van a veszélyhelyzetre, mivel kimondja, hogy különleges jogrendben az alapjogok a szükségesség és arányosság mértékét meghaladóan korlátozhatók. ${ }^{41}$ Minden válság más, ezért a megoldásokat nehéz a jog patikamérlegével adagolni. Ha a válság kezelése sikeres, akkor a választások során a kormány munkáját a választók ítélik meg, akik egyébként elszenvedik a válság negatív hatásait. A gazdasági eszközök túlzott törvényi mértékủ korlátozása akadályozhatja a kormányt a hatékony válságkezelésben. Erre mutat rá a koronavírus-járvány elleni véde-

38 Gazdasági válság 2020: A modern monetáris elmélet lesz a megoldás? Elérhető: https://elemzeskozpont.hu/ gazdasagi-valsag-2021-modern-monetaris-elmelet-lesz-megoldas (Letöltve: 2020. december 15.). A tanulmány rámutat arra, hogy van jó és rossz államadósság. Ha az állam a forrásokat beruházásra, gazdasági növekedésre vagy a jövőbeni gazdasági növekedés megalapozására költi, akkor ez nem okoz gondot az államháztartási gazdálkodás számára.

39 Gst. 38/A. \$.

40 Salgó, 2020, 15-16. o.

41 Alaptörvény 54.cikk (1) bekezdés: „Különleges jogrendben az alapvető jogok gyakorlása - a II. és a III. cikkben, valamint a XXVIII. cikk (2)-(6) bekezdésében megállapított alapvető jogok kivételével - felfüggeszthető vagy az I. cikk (3) bekezdése szerinti mértéken túl korlátozható." 
kezés céljából hozott törvény is, amely megerősítette és kiterjesztette átmenetileg a Kormány rendkívüli intézkedési jogát. ${ }^{42}$

A fiskális eszközöket feloszthatjuk a költségvetés bevételi oldalát érintő adójogi eszközökre és a kiadási összegeket érintő támogatási eszközökre. Az eszközök egy része már 2020 során bevezetésre került, míg mások csak 2021-tôl lépnek hatályba, és csak ettől kezdődően éreztetik a hatásukat. A hatásmechanizmus tekintetében a támogatási eszközök hatnak gyorsabban a gazdaságra, míg az adójogiak csak hosszabb távon éreztetik a hatásukat a gazdasági szereplőknél néhány kivételtől eltekintve, mint például az új adónem bevezetése. A válság okozta gazdasági problémák szükségessé tették a 2020-as költségvetés módosítását. ${ }^{43} \mathrm{~A}$ gazdaságvédelmi intézkedések keretében a jogalkotó több ezer milliárd forintos nagyságrendben csoportosított át költségvetési előirányzatokat, amelyből két külön alapot hozott létre a költségvetésben, amelyet továbbvisz a 2021-es költségvetési évre a járványügyi kiadásokra és a gazdaságvédelemre. ${ }^{44}$ Ezt indokolja, hogy 2020-ban a járványügyi veszélyhelyzet nem szúnik meg, tehát annak hatása lesz 2021-ben is a gazdaságra és a költségvetésre egyaránt. A gazdasági prognózisok jelentős pozitív változást jeleznek a 2021-es gazdasági növekedésben, de az előrejelzések teljesülése függ attól, hogy meddig tart 2021-ben a járványügyi veszélyhelyzet. ${ }^{45}$ Jelenleg úgy tûnik, hogy 2021 első félévében még a veszélyhelyzet fogja uralni a társadalmat és a gazdaságot.

A Járvány Elleni Védekezési Alap a járványhelyzet kezelése céljából jött létre, amelynek forrása az Országvédelmi Alap beolvasztásából keletkező előirányzatok, továbbá kiemelendő két új adónem, a gépjármúadó átcsoportosítása, illetve a pártok támogatási összegének az 50\%-a. A két új adónem illeszkedik az adópolitikába abból a szempontból, hogy a kormány nem általános, az adóalanyok széles körét érintő adónemet vezetett be vagy növelte az adóterheket, hanem speciális, szektorális különadókat. A korábbi válság gyakorlatát követve különadót állapított meg a hitelintézetekre. ${ }^{46} \mathrm{Az}$ új adónem összefüggésben van a pénzügyi szervezeteket terheló különadóval, amelyet még 2006-ban a központi költségvetési egyensúly javítása érdekében hoztak, a közteherviselésben érvényesítendő szolidaritás jegyében. ${ }^{47} \mathrm{Az}$ új adó szúkebb adózói kört határoz meg, mivel a 2006-os szabály a pénzügyi szervezetekre terjed ki, addig az új szabály csak a hitelintézeti szektort érinti.

42 A koronavírus elleni védekezésról szóló 2020. évi XII. törvény. A törvény 2. \$-a kimondja, hogy a nemzetgazdaság stabilitásának garantálása érdekében a Kormány rendeletével egyes törvények alkalmazását felfüggesztheti, törvényi rendelkezésektől eltérhet és egyéb rendkívüli intézkedéseket hozhat.

43 Magyarország 2020. évi központi költségvetésének a veszélyhelyzettel összefüggő eltérő szabályairól szóló 92/2020. (IV. 6.) Korm. rendelet (a továbbiakban: Költségvetési r.).

44 Magyarország 2021. évi központi költségvetéséről szóló 2020. évi XC. törvény (a továbbiakban: 2021-es költségvetési tv.).

45 Jackson et al., 2020, 5-13. o. A különféle előrejelzések (IMF, World Bank, OECD) 2,8\% és 5,2\% közé teszik a gazdasági növekedést 2021-ben.

46 A Gazdaságvédelmi Akcióterv végrehajtása érdekében a Járványügyi Alap feltöltését szolgáló, hitelintézetek járványügyi helyzettel összefüggő különadójáról szóló 108/2020. (IV. 14.) Korm. rendelet.

47 Az államháztartás egyensúlyát javító különadóról és járadékról szóló 2006. évi LIX. törvény. 
Továbbá az új hitelintézeti különadó ideiglenes, 2020. évre szól, és lehetőség van 5 év alatt egyenlő részletekben elszámolni a korábbi pénzügyi szervezetek különadójával szemben. A másik új adónem, amely az alap feltöltésére szolgál, a kiskereskedelmi adó. ${ }^{48} \mathrm{Az}$ adónem elsődlegesen a nagyobb árbevételủ adózókat sújtja jobban. Az adó szintén határozott időre bevezetett különadó, mivel a veszélyhelyzet megszűnését követő 30 napig áll fenn. Az alap harmadik adójogi forrása a gépjármúadó, amelyet az önkormányzati bevételek közül von el a Kormány. A gépjármúadó 40\%-a illette meg az önkormányzatokat a 2020-as költségvetés alapján, amely a módosítás során teljes összegben a központi költségvetéshez került, az alap feltöltésére. ${ }^{49}$

A különleges jogrenddel összefüggésben létrejött másik - költségvetési szempontból jelentősebb - alap a Gazdaságvédelmi Alap. Ebbe az alapba kerültek átcsoportosításra az egyes minisztériumok megtakarított forrásai, illetve ide olvadt be a Nemzeti Foglalkoztatási Alap..$^{50} \mathrm{Az}$ alapba sok program került, jelentős pénzügyi forrásokkal. Az alap finanszírozza többek között az egyedi és általános térségfejlesztési programokat (Magyar Falu Program, Modern Városok Program), a közlekedésfejlesztési és az energia- és klímapolitikai fejlesztéseket, a versenyképességet növelő fejlesztéseket (egészségipari fejlesztések), a nagyvállalati beruházásokat, a sport-, kulturális és turisztikai beruházásokat. Az alapon belül elkülönített részként múködik a Gazdaságvédelmi Foglalkoztatási Alap.

A központi költségvetés alrendszerét érintő átcsoportosítások mellett az önkormányzati alrendszert érintő jogszabályi módosításokra egyaránt sor került. A módosítás célja kettős volt: egyrészt forrásátcsoportosítás a központi költségvetés számára, mint a gépjármúadóból származó bevétel, másrészt az önkormányzati díj- és adócsökkentés, amivel a vállalkozók és magánszemélyek részére nyújt a Kormány közvetett támogatást.

A helyi önkormányzati autonómia elengedhetetlen feltétele a gazdasági önállóság, amit az alkotmányos rendelkezések egyaránt alátámasztanak, és a Helyi Önkormányzatok Európai Chartája is megerősít..$^{51} \mathrm{~A}$ forrásszabályozás pedig szorosan összefügg a közfeladat-

48 A Gazdaságvédelmi Akcióterv végrehajtása érdekében a Járványügyi Alap feltöltését szolgáló kiskereskedelmi adóról szóló 109/2020. (IV.14.) Korm. rendelet. 500 millió árbevételig $\% \%$ az adó, csak ennél magasabb árbevétel esetén merül fel a sávosan változó adófizetési kötelezettség.

49 2021-es költségvetési tv. Az alap a 2021-es költségvetésben már az Egészségbiztosítási Alappal együtt szerepel mint Egészségbiztosítási és Járvány Elleni Védekezési Alap, de két külön címre osztva és elkülönítve szerepeltetve a két alapot.

50 Magyarország konvergenciaprogramja 2020-2024. Elérhető: https://ec.europa.eu/info/sites/info/files/2020european-semester-convergence-programme-hungary_hu.pdf (Letöltve: 2020. december 15.); www. portfolio.hu/gazdasag/20201226/szep-csendben-hatalmasra-hizott-a-magyar-gazdasagvedelmimentocsomag-463178 (Letöltve: 2020. december 15.). A Gazdaságvédelmi Alapba 2020-ban mintegy 1300 milliárd forint volt előirányozva, de ez mintegy 4000 milliárd forintra növekedett az év végére, ami a GDP 9\%-át teszi ki. 2021-ben 2600 milliárd forint felett rendelkezik az alap a költségvetési előirányzatok alapján. Az alapba tartozik a Gazdaságvédelmi Foglalkoztatási Alap, amely a Nemzeti Foglalkoztatási Alap helyébe lép.

51 Lentner, 2017, 136-137. o. 
ellátással. ${ }^{52} \mathrm{Az}$ állam ugyan fokozatosan átvett feladatokat az önkormányzatoktól, tehát centralizáció indult el ezen a területen, de alapvető közszolgáltatások még maradtak az önkormányzatoknál, amelyek finanszírozásához az önkormányzati saját bevételek nélkülözhetetlenek..$^{53}$ A veszélyhelyzet azonban felülírta ezeket az elveket, az állam törekszik a források központosítására, és a veszélyhelyzeti védekezésre és a gazdaságvédelemre átcsoportosítani ezeket. Ennek következtében viszont nehéz helyzetbe kerülhetnek az önkormányzatok, mivel nem biztos, hogy megfelelő színvonalon tudják ellátni a településüzemeltetési feladatokat, illetve a válság következtében fellépő szociális problémákkal is szembe kell nézniük. A Kormány ezt úgy próbálja orvosolni, hogy a hiányzó forrásokat visszapótolja a kisebb települések esetében automatikusan, míg a nagyvárosok esetében diszkrecionálisan, egyedileg megvizsgálva az önkormányzatok forráshiányát. Ezzel a Kormány egyfajta kiegyenlítő mechanizmust érvényesít, a jobb gazdasági helyzetben lévő önkormányzatoktól forrást von el, míg a rosszabb helyzetben lévő önkormányzatok számára forrást biztosít. Az biztos, hogy a gazdasági válság mély nyomot fog hagyni az állam és az önkormányzatok gazdálkodásában egyaránt.

Három fôbb, az önkormányzati gazdálkodást jelentős mértékben befolyásoló rendelkezésre került sor:

- gépjármúadó elvonása;

- iparüzési adó módosítása;

- díjak korlátozása.

A gépjármúadó elvont része a járványügyi alapba kerül a korábban említettek szerint, aminek következtében ideiglenesen megszűnik ennek a központi adónak a megosztása a központi és az önkormányzati államháztartási alrendszer között. ${ }^{54} \mathrm{~A}$ megosztás egyébként egyedileg kerül szabályozásra a mindenkori költségvetési törvényekben, és az arány is folyamatosan változott több év távlatában, de az utóbbi években a 40\%-os arány állandósult. Az önkormányzatok számára ez fontos forrás lehetne a válságos időkben is, mivel ez nem változik lényeges mértékben a válság hatására.

Az iparüzési adó azonban lényegesen nagyobb mértékben érinti a nagyobb településeket, különösen azokat, ahol jelentős vállalkozási tevékenységet végeznek, és ezt arányaiban a kis- és középvállalkozások folytatják. A forráselvonás szintén az önkormányzatok pénzügyi autonómiáját szúkíti átmenetileg, a járványügyi veszélyhelyzet idejére. ${ }^{55} \mathrm{~A} 2021$-es adóévre vonatkozóan az iparúzési adó mértéke 1\%-ra csökken a kis- és középvállalkozások

\footnotetext{
52 Horváth M.-Péteri-Vécsei, 2014, 121-123. o.

53 Horváth M., 2014, 185-188. o.

54 A Költségvetési r. kimondja, hogy a 2020. évi költségvetési törvénytől eltérően állapítja meg a gépjárműadó megosztását, és 2020. január elsejétől visszamenőleg a beszedett gépjármúadó teljes összege a központi költségvetést illeti meg.

55 Kecső-Tombor, 2020, 22-30. 0.
} 
számára, kivéve, ha ettől alacsonyabb mértékben került megállapításra az adó. Ebben az esetben az alacsonyabb kulcs az irányadó. ${ }^{56} \mathrm{Az}$ iparúzési adót érinti továbbá a különleges gazdasági övezetek létrehozása, mivel az adómegállapítási jogkör a települési önkormányzattól a megyei önkormányzathoz kerül, a települési önkormányzat részére az illetékességi területén fennálló iparúzésiadó-kötelezettség megszűnik. A különleges gazdasági övezetbe jelentős vállalkozások tartozhatnak, magas adóerő-képességgel, így források allokációjára kerülhet sor a települési és a megyei önkormányzat között. Azonban a törvény korlátozza és feltételhez köti a Kormány jogát az ilyen övezetek kijelölésére, a bevezető rendelkezések által meghatározott keretek mellett is. Utal a jogalkotó arra, hogy kiemelt jelentőséggel bíró területek esetében munkahelyek megőrzése és gazdasági tevékenységek kedvező körülményeinek megteremtése érdekében van lehetősége a Kormánynak ilyen övezet kijelölésére a korlátozó feltételek mellett..$^{57}$

A harmadik, az önkormányzati alrendszer gazdálkodását jelentősen érintő szabály a díjak korlátozása. ${ }^{58} \mathrm{~A}$ Kormány a gazdaságvédelmi intézkedések keretében 2021 . december 31-ig az önkormányzat és az önkormányzat által fenntartott, alapított szervezetek, gazdálkodó szervezetek közszolgáltatásra megállapított díját maximálta, a díjemelést, új díj bevezetését, a díj új kötelezetti körre való kiterjesztését megtiltotta. A rendelkezés tehát mérsékli a vállalkozók és a lakosság terheit, de ugyanakkor az önkormányzatok forrásbővitését is korlátozza.

A fentieken túl általában a gazdasági válság kezelésével összefüggésben hozott szabályok és intézkedések több területre bonthatók: $:^{59}$

- munkahelymegőrzés és munkahelyteremtés;

— kiemelt ágazatok és hazai vállalkozások támogatása;

- családok támogatása;

- ellátásbiztonság fenntartása.

A munkahelyek megőrzése, illetve új munkahelyek teremtése kiemelt feladatként fogalmazódott meg a kormányprogramban. A keresletcsökkenés következtében a munkavállalók elbocsátásokra, illetve a munkaidő csökkentésére kényszerülnek. A Kormány támogatást vezetett be a rövidített munkaidő esetén a kieső munkaidőre eső nettó bérrész 70\%-áig. Továbbá a kiemelt ágazatokban nem kell munkáltatói járulékot fizetni, a munkavállalók járuléka csökken, így a nyugdíjárulék fizetésére sem kerül sor, az egészségbiztosítási díj pedig

56 639/2020. (XII. 22.) Korm. rendelet a koronavírus-világjárvány nemzetgazdaságot érintő hatásának enyhítése érdekében szükséges egyes intézkedésekről. A rendelet az 1990. évi C. törvény szerinti vállalkozót, adóalanyt érinti, amely a 2004. évi XXXIV. törvény szerint kis- és középvállakozásnak minősül, és a nettó árbevétele nem haladja meg a 4 milliárd forintot.

57 A gazdasági övezetről és a hozzá kapcsolódó egyes törvények módosításáról szóló 2020. évi LIX. törvény 1. \$.

58 Vígvári, 2002, 177. o.

59 Magyarország konvergenciaprogramja 2020-2024. Elérhető: https://ec.europa.eu/info/sites/info/files/2020european-semester-convergence-programme-hungary_hu.pdf(Letöltve: 2020. december 15.). 
a törvényi minimumra csökken. A szociális hozzájárulási adó 2\%-os csökkentése szintén a foglalkoztatást segíti elő, mint az adókönnyítések. Speciális fizetési könnyítések és adómérséklési lehetőségek állnak rendelkezésre a munkáltatók számára, mint például a munkaerőpiaci járulék átmeneti eltörlése. Egyes kiemelt ágazatokban tevékenykedő vállalkozók (többek között turizmus és vendéglátás, egészségipar, élelmiszeripar) számára adókönnyítéseket és adóelengedést alkalmaz a Kormány (a kisadózó vállalkozások és kisvállalati adó szerint adózók esetében). ${ }^{60} \mathrm{~A}$ munkahelyteremtés érdekében a beruházások és a technológiai fejlesztés támogatása került elótérbe. Kiemelt ágazat a környezetvédelem mellett a jövőbeni fejlődés előtt álló iparágak, mint például a mesterséges intelligencia, a kvantumtechnológia, de idesorolhatók azok az ágazatok is, amelyeket fokozottan érintett a gazdasági válság. A humánerőforrás biztosítása érdekében pedig az átképzéshez, továbbképzéshez biztosítanak támogatást az egyes programok. A családok számára a lakásberuházások támogatása mellett hiteltörlesztési moratórium biztosított, továbbá a lejáró gyes-, gyed-, gyet-ellátások meghosszabbításra kerülnek a veszélyhelyzet idejére.

A támogatáspolitika tehát a munkahelyek megtartására koncentrál rövid távon, de nem növeli a munkanélküliek ellátását. Ez az utóbbi évek gazdaságpolitikájának a következetes folytatása, amely a foglalkoztatás növelését tekinti fontos szempontnak, és kevésbé koncentrál az álláskeresőkre. Az utóbbi évek munkaerőhiánya ezt indokolta is, de a gazdasági válság okozta sokkhelyzetben célszerû́ lenne legalább átmeneti időre növelni a munkanélküli ellátások mértékét és idejét egyaránt.

A veszélyhelyzetben kiemelt jelentősége van a közszolgáltatások zökkenőmentes biztosításának, ső́t a társadalmi érdek érvényesítése során egyes gazdálkodó szervezetek múködése állami felügyelet alá vonható. Azoknál a közszolgáltatásoknál, amelyek állami vagy önkormányzati irányítás vagy közvetett tulajdon alatt állnak, könnyebben érvényesíthető a közérdek veszélyhelyzet esetén, mint a közszférától független vállalkozások esetén. Azonban ez utóbbi esetben is lehet olyan veszélyhelyzeti esemény, amely megköveteli a múködés állami felügyelet révén történő fenntartását, mint ahogy ez megtörtént 2020-ban a nemzetgazdasági szempontból jelentős vállalkozások esetében. ${ }^{61}$

60 A kisadózó vállalkozások tételes adójáról és a kisvállalati adóról szóló 2012. évi CXLVII. törvény.

61 Lentner-Cseh, 2020, 4. o. A szerzők rámutatnak arra, hogy Honvédelmi Irányító Törzs múködik 71, az ország szempontjából létfontosságú vállalatnál. Az állam közüzemi szektorbeli jelentőségére utaló további szakirodalom: Lentner-Molnár, 2020, 1-6. o.; Lentner, 2015, 763-783. o. 


\section{Monetáris politika a járványügyi veszélyhelyzet okozta gazdasági válságban}

A fiskális politika mellett a monetáris politika segíti a gazdaságpolitikai célkitúzéseket. ${ }^{62} \mathrm{~A}$ monetáris politika független a fiskális politikától, de mivel két összefüggő rendszerről van szó, a monetáris és fiskális politika sikerességének fontos alapköve a megfelelő koordináció. ${ }^{63} \mathrm{~A}$ magyar jegybanktörvény is utal arra, hogy a jegybank az elsődleges céljának veszélyeztetése nélkül támogatja a kormány gazdaságpolitikájátt. ${ }^{64} \mathrm{~A}$ monetáris politika megvalósítása érdekében széles körủ eszközrendszer áll a jegybank rendelkezésére, amelyek révén befolyásolhatja a pénz- és hitelkínálatot, valamint a pénz- és hitelkeresletet. ${ }^{65}$ Ezeket az eszközöket tekinthetjük hagyományos jegybanki eszközöknek. A korábbi gazdasági válság ${ }^{66}$ azonban már új trendeket hozott a világ vezető jegybankjainak monetáris politikájában. A szakirodalom rámutat arra, hogy a jegybanki eszköztár új elemekkel egészült ki, és a gazdasági válság kezelésében a jegybankok szerepe jelentősen felértékelődött. A konvencionális eszköznek számító kamatmérséklés a nulla kamatszint alatt már nem fejtette ki a hatását kellő mértékben. Így egyes jegybankok értékpapír-vásárlási programokat hirdettek, ezzel növelve a pénzpiaci likviditást. ${ }^{67} \mathrm{Az}$ Európai Központi Bank új eszközként a nagyvállalati hitelkövetelések fedezetként való elfogadását alkalmazta a 2008-as válságban, amely fontos eszközzé vált a válság után is az euróövezeti monetáris politikában. ${ }^{68}$

A jelenlegi válsággal kapcsolatos jegybanki eszközrendszer tovább bővült a korábbiakhoz képest, nem csak volumenében. Az Egyesült Államok jegybankja (FED) a gazdasági válság kapcsán gyorsan lépett fel, a kamatvágás mellett mennyiségi enyhítést jelentett be, keretösszeg nélkül. A FED az eszközvásárlásai keretében államkötvényt, ingatlanalapú jelzáloghitelt és vállalati kötvényeket egyaránt vásárolt. ${ }^{69} \mathrm{~A}$ magyar jegybank szintén változtatott a monetáris politikai eszköztárán a gazdasági válság hatásainak tompítása érdekében.

62 Nagy, 2006, 239-270. o.

63 Sivák-Vígvári, 2012, 204-205. o.

64 A Magyar Nemzeti Bankról szóló 2013. évi CXXXIX. törvény (a továbbiakban: MNBtv.) 3. \$. Az MNB elsődleges célja az árstabilitás elérése és megőrzése.

65 A monetáris politika eszközrendszerébe tartozik a betét elfogadása és hitel nyújtása, a nyílt piaci múveletek és visszavásárlási megállapodások, a saját értékpapírok kibocsátása, az árfolyam és kamatok meghatározása és befolyásolása, az értékpapír-leszámítolás és -visszleszámítolás, kötelező tartalék szabályozása.

66 Nagy, 2020, 85-88. o.

67 Lentner, 2019, 184-185. o.

68 A Magyar Nemzeti Bank monetáris politikai eszköztára a COVID-19-válság időszakában. Elérhető: www.mnb.hu/ letoltes/jegybanki-eszkoztar-2020-Covid19.pdf (Letöltve: 2020. december 15.).

69 Elérhető: https://elemzeskozpont.hu/gazdasagi-valsag-2021-modern-monetaris-elmelet-lesz-megoldas (Letöltve: 2020. december 15.). 
Az MNB a Covid-19-válságra vonatkozó összegzésében részletesen meghatározza a monetáris politika céljait és az ehhez rendelt eszközöket. ${ }^{70}$

Az MNB az eszközöket a célok alapján három területre bontotta:

- likviditás biztosítása;

— a rövid futamidejú hozamok rugalmasabb alakíthatósága;

— hosszú futamidejú hozamokra ható eszközök.

A likviditás növelése érdekében a jegybank új eszközöket alkalmaz. Az MNB a jegybankképes fedezetek körét bővítette a nagyvállalati hitelekkel, azaz a nagyvállalatokkal szembeni követelésekkel. Ennek következtében a magyar jog hatálya alá tartozó, egymilliárd forint feletti tőketartozások vonhatók be a jegybanki fedezetek körébe. Továbbá a jegybanki források elérhetôvé váltak a befektetési alapok számára, így részükre is lehetôvé vált a jegybanki hitelfelvétel a befektetési jegyek fedezete mellett (denominált értékpapír- és ingatlanalapok befektetési jegyei). Hosszú távú jegybanki hiteleszköz is bevezetésre került a pénzpiaci feszültség enyhítése érdekében. Így a pénzpiaci stabilitást hivatott biztosítani az MNB által nyújtott, maximálisan ötéves futamidejû, fix, legalább a jegybanki alapkamaton kamatozó, fedezett hitel. A tartalékkötelezettséget érintő rendelkezés szintén növelte a likviditást. A jegybank felfüggesztette a tartalékkötelezettséget, így az előírások nem teljesítése esetén nem alkalmaz jogkövetkezményt. ${ }^{71}$

A rövid futamidejủ hozamok rugalmassága érdekében a jegybank az egyhetes betét eszközét vezette be ismét, illetve a kamatfolyosót szimmetrikussá tette. A kamatfolyosó közepe lett a jegybanki alapkamat, míg a két széle az egynapos betéti kamat és az egynapos, egyhetes fedezett hitel kamata. Ez biztosítja a rugalmasságot a monetáris transzmisszió számára.

A hosszú futamidejú hozamokra ható eszközök bevezetése szintén a likviditás növelését szolgálja. A jegybank egyrészt átalakította a Növekedési Kötvényprogramot, másrészt új programként elindította a Növekedési Hitelprogram Hajrát, amellyel tovább bővülhet a hazai vállalkozások finanszírozása. Ez előnyös finanszírozást jelent, de nem biztos, hogy teljes mértékben új likviditást hoz, hiszen a korábbi hiteleiket kiválthatják ezzel a vállalkozások. ${ }^{72}$ A Növekedési Kötvényprogram ${ }^{73}$ módosításával enyhítette a feltételeket a jegybank,

70 Elérhető: www.mnb.hu/letoltes/jegybanki-eszkoztar-2020-Covid19.pdf (Letöltve: 2020. december 15.). A monetáris eszköztár elsősorban ez alapján kerül bemutatásra a továbbiakban.

71 MNBtv. 19-20. \$. Az MNB elnöke rendeletében elöírhatja, hogy a pénzügyi intézmények és a befektetési vállalkozások idegen forrásaik, egyes eszközeik és mérlegen kívüli tételeik meghatározott arányában tartalékot helyezzenek el az MNB-nél. Az MNB elnöke rendeletben szabályozza a tartalék kiszámítására, képzésének és elhelyezésének módjára, valamint a teljesítés elmaradása esetén alkalmazandó intézkedésekre vonatkozó elóírásokat.

72 Palócz-Matheika, 2020, 586. o.

73 A Növekedési Kötvényprogram a vállalati kötvénypiac likviditásának növelése érdekében indult 2019-ben. A program keretében az MNB 1150 milliárd forint keretösszegben nem pénzügyi vállalatok által kibocsátott kötvényeket vásárolt. Elérhetô: www.mnb.hu/monetaris-politika/novekedesi-kotvenyprogram-nkp (Letöltve: 2020 . december 15.). 
így az egy vállalatcsoporttal szembeni kitettsége 50 milliárd forintra növekedett, illetve a kötvények futamideje 20 évre változott. Idesorolható a már említett hosszú hiteleszközök bevezetése és az eszközvásárlási program. Az utóbbi keretében állampapír- és jelzáloglevél-vásárlási programokról döntött a jegybank. Az állampapír-vásárlások kerete nem meghatározott, a központi bank addig folytatja, ameddig ezt a gazdasági válság indokolja. A 2018-ban elindított, majd 2020-ban újraindított jelzáloglevél-vásárlási program keretében az MNB fix kamatozású, forintban kibocsátott jelzálogleveleket vásárol az elsődleges és másodlagos piacon, amelyeknek legalább egy év a hátralévő futamideje, és a Budapesti Értéktôzsdén nyilvános forgalomban vannak. A jegybank tehát a hagyományos monetáris politikai eszközök mellett olyan további eszközöket használ a likviditás bővítése érdekében, amelyeket a jelentős, a pénzpiacon meghatározó szerepet betöltő jegybankok is alkalmaznak.

A válság nem hagyja érintetlenül a bankrendszer múködését sem, hiszen a válsággal nő a pénzügyi intézmények kockázata. A szakirodalom rámutat viszont arra, hogy a jelenlegi válság felkészültebben érte a bankrendszereket, mivel a 2008-as válság után erőteljes reguláció következett be. ${ }^{74} \mathrm{~A}$ kockázatok azonban egyedi intézményi és rendszerszinten egyaránt jelentkezhetnek. A bankok múködési kockázata változott, új kockázati tényezők jelennek meg a világjárvány következtében. Fontos feladata a hitelintézeteknek, hogy a kockázatokból ne vagy csak kisebb veszteség keletkezzen. A szakirodalmi elemzés kiemeli azokat a kockázatokat, amelyek meghatározóvá váltak a járvány következtében, és az alábbiak szerint rámutat ezek jelentőségére. ${ }^{75}$

A geopolitikai kockázat jelentősége nőtt, a járványhelyzet miatt kialakult gazdasági válság kiterjed az egész világgazdaságra, és nehezen prognosztizálható a válságból történő kilábalás ideje és mértéke. Fontos kockázati elem a reziliencia, azaz a vállalkozás azon képessége, hogy egy esetleges válság után hogyan tudja helyreállítani a múködését. A tevékenységgel összefüggésben pedig az outsourcing kockázata lényeges, azaz hogy a külső partner fenn tudja-e tartani a múködését a munkaeró és az irodai feltételek kiesése esetén. A vírus miatt megnövekedett az otthoni munkavégzés, illetve a távoli munkavégzés, ami újabb kockázatokat hordoz, egyrészt a fegyelemcsökkenés, másrészt a gyors átállás miatt. Ebből adódóan nő a belső és külső csalások, illetve a kibertámadások száma. Az utóbbi esetben adatvesztés, adatlopás vagy rendszerleállás egyaránt előfordulhat. Ezek a kockázatok szorosan összefüggenek a munkavállalók egyéni kockázatával és az ezzel összefüggő szervezeti kockázattal. Ezek szintén nőttek a távoli munkavégzés következtében.

A bankok múködését szintén befolyásolja a Kormány által elrendelt hiteltörlesztési moratórium, amely a vállalkozások és a háztartások számára egyaránt lehetôvé teszi a hiteleik meghosszabbítását, ami szintén a likviditást növeli, segíti a vállalkozások múködését. A ház-

74 Terták-Kovács, 2020, 372-373. o.

75 Tamásné Völneki, 2020, 325-327. 0. 
tartások gazdálkodására szintén hatással van az előbbi mellett a fogyasztási hitelek teljes hiteldíjmutatójának maximalizálása. ${ }^{7}$

Mindezek a kockázatok egyben lehetőséget teremtenek a jogalkotó számára, hogy újraszabályozzon egyes területeket a tapasztalatokból kiindulva, hiszen nem biztos, hogy ez az utolsó ilyen járványügyi veszélyhelyzet. A tapasztalatok leszúrésére pedig kiváló lehetőséget teremt a tudományos kutatások folytatása.

\section{Irodalomjegyzék}

BALÁzs, P. (2020) 'A Covid-19-válság integrációs hatásai', Köz-gazdaság, 15(2), 5-12. o.

BARCZA, GY. (2015) 'Az államadósság szerepének változása a közgazdaságtanban és a magyar adósságkezelés alapelvei', Pénzügyi Szemle, 60(4), 444-457. o.

BESSENYEI, I. (2020) 'A fóáramú közgazdaságtan előrejelzése a koronavírus-járvány várható következményeiről', Tudásmenedzsment, 21(1), 181-185. o.

Вотоs, K. (2020) 'Élet és megélhetés. A gazdaságelmélet és a gyakorlat változásai a válság után', Pénzügyi Szemle, 65(3), 385-397. o.

Czeczeli, V., Kolozsi, P. P., Kutasi, G., Marton, Á. (2020) 'Gazdasági kitettség és válságállóság exogén sokk esetén', Pénzügyi Szemle, 65(3), 323-349. o.

Csû́Rös, G. (2015) Uniós pénzügyek. Az európai integráció fejlődésének pénzügyi jogi vizsgálata. 1. kiadás. Budapest: HVG-ORAC Kft.

CsÛ́Rös, G. (2018) 'Az állam (költségvetés) és a pénzügyi szektor közötti kapcsolat gyengítésére irányuló uniós intézkedések' in Árva, Zs., Szikora, V. (szerk.) A fogyasztók védelmének új irányai és kihivásai a XXI. században. 1. kiadás. Debrecen: Debreceni Egyetem Állam- és Jogtudományi Kar

CsÛ́RÖs, G. (2019) 'Erősebb stabilizáció az uniós közpénzügyekben?' in Halász, Zs. (szerk.) Magistra et Fautrix. Halustyik Anna emlékére. 1. kiadás. Budapest: Pázmány Péter Katolikus Egyetem Jog- és Államtudományi Kar

DRINóczI, T. (2012) 'Gazdasági alkotmány az Alaptörvényben', Pázmány Law Working Papers, 2012/33, 1-22. o.

HaLÁsz, Zs. (2018) Az Európai Unió költségvetésének szabályozása. 1. kiadás. Budapest: Pázmány Press

HaLmai, P. (2014) Krízis és növekedés az Európai Unióban. Európai modell, strukturális reformok. 1. kiadás. Budapest: Akadémiai Kiadó

HalmaI, P. (2020a) Európai gazdasági integráció. 1. kiadás. Budapest: Dialóg-Campus Kiadó

76 Magyarország konvergenciaprogramja 2020-2024. Elérhető: https://ec.europa.eu/info/sites/info/files/2020european-semester-convergence-programme-hungary_en.pdf(Letöltve: 2020. december 15.). 
HalmaI, P. (2020b) Mélyintegráció. A Gazdasági és Monetáris Unió ökonómiája. Budapest: Akadémiai Kiadó

HoRváth, M. T. (szerk.) (2014) Külön utak - Közfeladatok megoldásai. 1. kiadás. Budapest: Dialóg Campus

HoRVÁth, M. T., PÉTERI, G., VÉCSEI, P. (2014) 'A helyi forrásszabályozási rendszer magyarországi példája, 1990-2012', Közgazdasági Szemle, 61(2), 121-147. o.

Jackson, J. K., WeIss, M. A., SChWARzenberg, A. B., Nelson, R. M. (2020) ‘Global Economic Effects of COVID-19', Congressional Research Service [Online]. Elérhetô: www.wita.org/atpresearch/global-economic-effects-Covid/ (Letöltve: 2020. augusztus 12.)

KÁDÁR, P. (2021) 'A pandémia kezelése mint a nemzeti ellenálló képesség „tesztje”, Honvédségi Szemle, 149(2), 3-13. o.

KEcső, G. (2012) 'Adósságfékek az államháztartásban: költségvetési politika rövid pórázon', Jogi Tanulmányok, 2012/1, 417-430. o.

KECSő, G. (2018) 'Az Alaptörvény hatása az államháztartási jogra - különös tekintettel az eladósodás fékezésére', Közjogi Szemle, 11(3), 35-46. o.

Kecső, G., TомBoR, Cs. (2020) A helyi adók szabályozása és joggyakorlata Magyarországon külföldi kitekintéssel - különös figyelemmel az iparúzési adóra és a helyi vagyonadók arányosságára. 1. kiadás. Budapest: Nemzeti Közszolgálati Egyetem, Közigazgatási Továbbképzési Intézet KoppáNY, K. (2020) 'A kínai koronavírus és a magyar gazdaság kitettsége', Közgazdasági Szemle, 17(5), 433-455. o.

Kovács, Á. (2016) 'A Költségvetési Tanács a magyar Alaptörvényben’, Pénzügyi Szemle, 61(3), 320-337. 0.

LENTNER, Cs. (2015) 'A vállalkozás folytatása számviteli alapelvének érvényesülése közüzemi szolgáltatóknál és költségvetési rend szerint gazdálkodóknál - magyar, európai jogi és eszmetörténeti vonatkozásokkal' in Lentner, Cs. (szerk.) Adózási pénzü̈ytan és államháztartási gazdálkodás: Közpénzügyek és államháztartástan II. 1. kiadás. Budapest: Nemzeti Közszolgálati Egyetem és Tankönyvkiadó Zrt.

LENTNER, Cs. (2017) Közpénzügyi menedzsment. 1. kiadás. Budapest: Dialóg Campus

LENTNER, Cs. (2019) A magyar állampénzügyek fejlődéstörténete a dualizmus korától napjainkig. 1. kiadás. Budapest: L'Harmattan Kiadó.

LENTNER, Cs., CsEH, B. (2020) 'Állami tulajdonban lévő közüzemi vállalatok múködésfenntartásának egyes gazdasági és jogszabályi kérdései vészhelyzet esetén', Gazdaság és Jog, 28(5), 1-4. o.

LENTNER, Cs., MOLNÁR, P. (2020) 'Budapesti közüzemi szolgáltatások egyes szabályozási és hatékonysági kérdései a 2010-es állampénzügyi reform után', Pro Publico Bono: Magyar Közigazgatás, 8(1), 2-21. o.

MURAKÖZY, L. (2010) 'Válságok állama - államok válsága’, Közgazdasági Szemle, 57(8), 779-797. o. Muraközy, L. (2012) Államok kora. Az európai modell. 1. kiadás. Budapest: Akadémiai Kiadó NAGY, Z. (2006) 'A monetáris szervezet és tevékenység jogi szabályozása' in Károlyi, G. (szerk.) Gazdasági közjog. 1. kiadás. Debrecen: Debreceni Egyetem Kossuth Egyetemi Kiadó 
NAGY, Z. (2014a) Költségvetési gazdálkodás. Budapest: Nemzeti Közszolgálati Egyetem, Vezetőés Továbbképző Intézet [Online]. Elérhető: http://m.ludita.uni-nke.hu/repozitorium/ bitstream $/$ handle $/ 11410 / 10533 /$ Teljes\%20sz\%C3\%B6veg? sequence $=1 \&$ is Allowed $=y$ (Letöltve: 2020. december 15.)

NAGY, Z. (2014b) Költségvetési jog. Budapest: Nemzeti Közszolgálati Egyetem, Vezető- és Továbbképző Intézet [Online]. Elérhető: https://nkerepo.uni-nke.hu/xmlui/bitstream/ handle/123456789/10534/Teljes\%20sz\%F6veg;jsessionid=FE84558EA5EE5A6EBA3A7B20C4 490D90? sequence=2 (Letöltve: 2020 . december 15.)

NAGY, Z. (2019) 'A kriptopénzek helye és szerepe a pénzügyi rendszerben', Miskolci Jogi Szemle, 14(2), 5-14. o.

NAGY, Z. (2020) 'A pénzügyi rendszer problémái és kihívásai a jogi szabályozás számára', Miskolci Jogi Szemle, 15(2), 85-92. o.

Palócz, É., Matheika, Z. (2020) 'Dilemmák a Covid-19-válság magyarországi gazdasági hatásairól' in Kolosi, T., Szelényi, I., Tóth, I. Gy. (szerk.) Társadalmi Riport-2020. 1. kiadás. Budapest: TÁRKI

SALGó, L. P. (2020) 'A hazai veszélyhelyzeti jogalkotás a kodifikátor szemével', Fontes Iuris, 6(2), 8-18. O.

SAMUelson, P. A., NoRdhaus, W. D. (2012) Közgazdaságtan. 19. kiadás. Budapest: Akadémiai Kiadó

SHILLER, R. J. (2020) Narratív közgazdaságtan. 1. kiadás. Budapest: HVG

SIMON, I. (2019) Pénzügyi jog I. 1. kiadás. Budapest: ELTE Eötvös

SIVÁk, J., VÍGVÁRI, A. (2012) Rendhagyó bevezetés a közpénzügyek tanulmányozásába. 1. kiadás. Budapest: Complex

Sivák, J., Szemlér, T., VÍGVÁRI, A. (2013) A magyar államháztartás és az Európai Unió közpénzügyei. 1. kiadás. Budapest: Complex

STIGLITZ, J. E. (2000) A kormányzati szektor gazdaságtana. 1. kiadás. Budapest: KJK-KERSZÖV SzEGEDI, L. (2019) 'A Gazdasági és Monetáris Unió intézményrendszere' in Bóka, J., Gombos, K., Szegedi, L. (szerk.) Az Európai Unió intézményrendszere. 1. kiadás. Budapest: Dialóg Campus

SzijÁRTó, N. (2020) 'Az Európai Unió gazdasága és a koronavírus: Az Európai Bizottság útkeresése', Kihivások, 2020/236. Budapest: Világgazdasági Intézet, Közgazdaság- és Regionális Tudományi Kutatóközpont

TAMÁSNÉ VÖLNEKI, Zs. (2020) 'Krízismenedzsment és müködési kockázatkezelés a pénzügyi szektorban a Covid-19 árnyékában', Gazdaság és Pénzügy, 2020/3, 313-329. o.

TeRTÁk, E., KovÁcs, L. (2020) 'A szociális védelem és a társadalmi kohézió kihívásai válsághelyzetben a pénzügyi szférában', Pénzügyi Szemle, 65(3), 364-384. o.

VÍGVÁRI, A. (2002) Közpénzügyek, önkormányzatipénzügyek. 1. kiadás. Budapest: KJK-KERSZÖV VÍGVÁRI, A. (2005) Közpénzügyeink. 1. kiadás. Budapest: KJK-KERSZÖV 